Original Research Article

\title{
A KAP study of pharmacovigilance among junior residents and interns of a tertiary care hospital
}

\author{
Rupa Arun Korde, Radhika M. S.*
}

Department of Pharmacology, SDM College of Medical Sciences and Hospital, Dharwad, Karnataka, India

Received: 28 August 2018 Accepted: 27 September 2018

*Correspondence to: Dr. Radhika M. S., Email: drrupa2@yahoo.co.in

Copyright: (C) the author(s), publisher and licensee Medip Academy. This is an openaccess article distributed under the terms of the Creative Commons Attribution NonCommercial License, which permits unrestricted noncommercial use, distribution, and reproduction in any medium, provided the original work is properly cited.

\begin{abstract}
Background: Pharmacovigilance is the science and activities relating to the detection, assessment, understanding and prevention of adverse effects or any other possible drug-related problems. An "adverse drug reaction" is any noxious, unintended and undesired effect of a drug, which occurs at a dose used in humans for prophylaxis, diagnosis, therapy or modification of physiological functions. Reporting of adverse events and adverse drug reactions is the commonest method utilized for generating safety data. Lack of awareness about Pharmacovigilance is one of the most important causes of such under-reporting. Spontaneous reporting system is considered the main mechanism of pharmacovigilance study for gathering information about ADRs. Hence this study was undertaken to assess the knowledge, attitude and practice regarding Pharmacovigilance among junior residents and interns in a tertiary care hospital.

Methods: A cross-sectional study was carried out in 134 doctors using prevalidated 20 item questionnaire with details of participant's information followed by questions regarding knowledge, attitude and prescribing practice of pharmacovigilance was used as a tool, administrated to all the resident doctors and the collected data was analysed.

Results: Present study revealed that knowledge about pharmacovigilance was not adequate to JRs and INTs. Survey results revealed that the knowledge of pharmacovigilance among doctors $63(88.73 \%)$ JR and $49(77.78 \%)$ INTs had a knowledge score of less than $50 \%$. This shows that only few doctors are aware about the pharmacovigilance programme. The assessment of questionnaire based on attitude regarding pharmacovigilance shows that 21 (29.58\%) JR and 17 $(26.98 \%)$ of INTs had attitude score of $70 \%$ and above. The attitude score was less compared to the knowledge score of JRs and INTs. 52 JR and 58 INTs stated that they have not been trained on how to report ADRs and basic orientation about pharmacovigilance which hinders the process of practicing pharmacovigilance. Conclusions: For the success of Pharmacovigilance programmes only knowledge and attitude regarding Pharmacovigilance is not enough as is evident from our study. Success of Pharmacovigilance programmes depend also upon the effective practice of Pharmacovigilance by healthcare professionals.
\end{abstract}

Keywords: Adverse drug reactions, attitude, knowledge, Pharmacovigilance, prescribing practice

\section{INTRODUCTION}

Pharmacovigilance is the science and activities relating to the detection, assessment, understanding and prevention of adverse effects or any other possible drug-related problems. ${ }^{1}$ An "adverse drug reaction" is any noxious, unintended and undesired effect of a drug, which occurs at a dose used in humans for prophylaxis, diagnosis, therapy or modification of physiological functions. ${ }^{2}$ Reporting of adverse events and adverse drug reactions is the commonest method utilized for generating safety data. ${ }^{3}$

Adverse drug reactions (ADRs) are important public health problem contributing to a considerable economic 
burden on the society and health care systems. ADRs lead to number of medical and economic consequences like prolong hospital stay; increase in the cost of treatment and increase in the risk of mortality. It is one of the important causes of hospitalization varying between $5 \%$ and $13 \%$ ADRs accounts for $0.2-24 \%$ of hospital admissions, $3.7 \%$ of the patient experiences fatal ADRs. ${ }^{4,5}$

The Uppsala Monitoring Centre (UMC, WHO), Sweden, maintains the international database of the adverse drug reaction reports around the world. It has been estimated that only $6-10 \%$ of all the ADRs are reported. ${ }^{6}$ Although, India is participating in the program, its contribution to the UMC database is $2 \%$ only; still, there is a lack of active participation required to increase spontaneous reporting. ${ }^{7}$

Reporting ADRs voluntarily by healthcare professionals is essential for success of pharmacovigilance programme and decreasing the risk of ADRs by pharmaceutical products. Despite many efforts and presence of large number of tertiary care facilities pharmacovigilance is still in its infancy. Findings from various studies have revealed that ADR reporting is linked to the KAP of the healthcare professionals..$^{8-10}$

Lack of awareness about Pharmacovigilance is one of the most important causes of such under-reporting. Spontaneous reporting system is considered the main mechanism of pharmacovigilance study for gathering information about ADRs. Hence this study was undertaken to assess the knowledge, attitude and practice regarding Pharmacovigilance among junior residents and interns in a tertiary care hospital.

Aim of the study was to evaluate the knowledge, attitude and practice of pharmacovigilance among junior resident doctors (JRs) and interns (INTs) at SDM College of Medical Sciences and Hospital Dharwad.

\section{METHODS}

Descriptive study was carried out at Department of Pharmacology, SDM College of medical Sciences and Hospital. Ethical approval was taken from the Institutional Ethics Committee prior to study.

The inclusion criteria were enrolment of junior residents and interns posted in various departments like medicine, surgery, paediatrics, obstetrics and gynaecology, skin and venereal diseases as well as the psychiatry departments and the exclusion criteria were senior residents, undergraduate students and Post graduate students and those who refused to give written consent were excluded from the study. The study was conducted for duration of one month from October 2016 to November 2016 and the study population was based on the inclusion criteria.

A total of 134 doctors 71 junior residents and 63 interns were participated in the survey. The participants were briefed about the nature and purpose of the study before subjecting to the questionnaire. Each participant was allotted 30 minutes for the completion of the study. Written informed consent was obtained from each participant. Informed consent was voluntary and freely given. A cross-sectional study was carried out using prevalidated 20 item questionnaire (Annexure- I) with details of participant's information followed by questions regarding knowledge, attitude and prescribing practice of pharmacovigilance was used as a tool, administrated to all the resident doctors.

\section{Statistical analysis}

The collected data was pooled and expressed as counts and percentages by statistical analysis which explores each variable in a data set separately. The results were analyzed by One way ANOVA followed by post hoc test using SPSS Software version 20 for windows. The results expressed are in mean \pm standard deviation mean.

\section{RESULTS}

Among 134 doctors participated in the study, 71 were junior residents and 63 interns. The study was conducted to assess the information about the knowledge, attitudes and the practices of pharmacovigilance.

Survey results revealed that the knowledge of pharmacovigilance among doctors $63(88.73 \%)$ JR and 49 (77.78\%) INTs had a knowledge score of less than $50 \%$. This shows that only few doctors are aware about the pharmacovigilance programme.

Table 1 shows response regarding knowledge about pharmacovigilance, only $31 \mathrm{JR}$ and 42 INTs defined pharmacovigilance correctly, 35 JR and 31 INTs would able to specify the important purpose of pharmacovigilance, the knowledge about the international center for ADR is known by very few participants (15 JR and 14 INTs). Only 53 JR and 42 INTs know that the Central Drugs Standard Control Organization is the regulatory body for monitoring

Another question sought information about the scales used to establish the causality of ADRs and according to the data only 13 JR 11 INTs gave a correct response. 19 JR and 15 INTs have the knowledge about the regional pharmacovigilance centre located at JSS Medical College and Hospital Mysore. Very minimal i.e., 13 JR and 16 INTs know that Vigibase is WHO online database' for reporting ADRs. Only $45 \mathrm{JR}$ and 47 INTs have the knowledge that ADR reporting can be done by physicians, nurses and pharmacists. The assessment of questionnaire based on attitude regarding pharmacovigilance shows that $21(29.58 \%)$ JR and $17(26.98 \%)$ of INTs had attitude score of $70 \%$ and above. The attitude score was less compared to the knowledge score of JRs and INTs.

Table 2 shows response regarding attitude of participants to Pharmacovigilance 67 JR and 62 INTs opined that ADR 
reporting was required. $38 \mathrm{JR}$ and 37 INTs stated ADR reporting is professional obligation for physicians. $40 \mathrm{JR}$ and 37 INTs agreed that ADR monitoring center should be established in every hospital. With respect to teaching Pharmacovigilance in details to health care professionals, $66 \mathrm{JR}$ and 59 INTs agreed to it.

Table 1: Response regarding knowledge of pharmacovigilance.

\begin{tabular}{|c|c|c|}
\hline Response to questions & JRs $n=$ number and (\%) & INTs $n=$ number and $(\%)$ \\
\hline Define Pharmacovigilance? & $\begin{array}{l}\text { Correct - } 31(43.6 \%) \\
\text { Incorrect - } 40(56.3 \%)\end{array}$ & $\begin{array}{l}\text { Correct - } 42(66.66 \%) \\
\text { Incorrect -21 }(33.33 \%)\end{array}$ \\
\hline Important purpose of Pharmacovigilance & $\begin{array}{l}\text { Correct - } 35(49.2 \%) \\
\text { Incorrect - } 32(45 \%)\end{array}$ & $\begin{array}{l}\text { Correct - } 31(43.6 \%) \\
\text { Incorrect - } 40(56.3 \%)\end{array}$ \\
\hline ADR should be reported within how many days & $\begin{array}{l}\text { Correct - } 48(67.6 \%) \\
\text { Incorrect - } 11(15.4 \%)\end{array}$ & $\begin{array}{l}\text { Correct - } 15(23.80 \%) \\
\text { Incorrect - } 47(74.60 \%)\end{array}$ \\
\hline International center for ADR is located in & $\begin{array}{l}\text { Correct - } 15(21.1 \%) \\
\text { Incorrect - } 44(61.9 \%) \\
N A-12(16.9 \%)\end{array}$ & $\begin{array}{l}\text { Correct - } 14(22.2 \%) \\
\text { Incorrect - } 49(77.77 \%)\end{array}$ \\
\hline $\begin{array}{l}\text { The agency in Unites States of America involved in } \\
\text { drug safety issues. }\end{array}$ & $\begin{array}{l}\text { Correct - } 54(76.05 \%) \\
\text { Incorrect - } 11(15.4 \%) \\
N A-6(8.4 \%)\end{array}$ & $\begin{array}{l}\text { Correct - } 42(66.66 \%) \\
\text { Incorrect - } 20(31.74 \%) \\
\text { NA - } 1(1.58 \%)\end{array}$ \\
\hline $\begin{array}{l}\text { In India which Regulatory body is responsible for } \\
\text { monitoring of ADR's? }\end{array}$ & $\begin{array}{l}\text { Correct - } 53(74.64 \%) \\
\text { Incorrect - } 12(16.90 \%) \\
\text { NA - } 6(8.4 \%)\end{array}$ & $\begin{array}{l}\text { Correct - } 42(66.6 \%) \\
\text { Incorrect - } 18(28.5 \%) \\
\text { NA - } 3(4.76 \%)\end{array}$ \\
\hline $\begin{array}{l}\text { Which of the following scales is most commonly } \\
\text { used to establish the causality of an ADR? }\end{array}$ & $\begin{array}{l}\text { Correct - } 13(18.3 \%) \\
\text { Incorrect - } 23(32.3 \%) \\
\text { NA - } 35(42.29 \%)\end{array}$ & $\begin{array}{l}\text { Correct - } 11(17.46 \%) \\
\text { Incorrect - } 37(58.73 \%) \\
\text { NA - } 15(23.80 \%)\end{array}$ \\
\hline $\begin{array}{l}\text { Match the ADR reporting systems to the respective } \\
\text { countries }\end{array}$ & $\begin{array}{l}\text { Correct - } 13(18.3 \%) \\
\text { Incorrect - } 25(35.21 \%) \\
\text { NA - } 33(46.47 \%)\end{array}$ & $\begin{array}{l}\text { Correct - } 14(22.22 \%) \\
\text { Incorrect - } 34(53.96 \%) \\
\text { NA - } 15(23.80 \%)\end{array}$ \\
\hline $\begin{array}{l}\text { One among these is a Regional Pharmacovigilance } \\
\text { centre? }\end{array}$ & $\begin{array}{l}\text { Correct - } 19(26.76 \%) \\
\text { Incorrect - } 39(54.6 \%) \\
N A-13(18.3 \%)\end{array}$ & $\begin{array}{l}\text { Correct - } 15(23.80 \%) \\
\text { Incorrect - } 47(74.60 \%) \\
\text { NA - } 1(1.58 \%)\end{array}$ \\
\hline $\begin{array}{l}\text { Which one of the following is the 'WHO online } \\
\text { database' for reporting ADRs? }\end{array}$ & $\begin{array}{l}\text { Correct - } 13(18.3 \%) \\
\text { Incorrect - } 43(60.56 \%) \\
\text { NA - } 15(21.12 \%)\end{array}$ & $\begin{array}{l}\text { Correct - } 16(25.39 \%) \\
\text { Incorrect - } 44(69.84 \%) \\
\text { NA - } 3(4.76 \%)\end{array}$ \\
\hline $\begin{array}{l}\text { Rare ADRs can be identified in the following phase } \\
\text { of a clinical trial }\end{array}$ & $\begin{array}{l}\text { Correct - } 40(63.38 \%) \\
\text { Incorrect - } 21(29.57 \%) \\
\text { NA - } 12(16.90 \%)\end{array}$ & $\begin{array}{l}\text { Correct - } 17(26.98 \%) \\
\text { Incorrect - } 15(\%) \\
\text { NA - } 1(1.58 \%)\end{array}$ \\
\hline $\begin{array}{l}\text { The healthcare professionals responsible for } \\
\text { reporting ADR in a hospital is/are }\end{array}$ & $\begin{array}{l}\text { Correct - } 45(63.38 \%) \\
\text { Incorrect - } 21(29.57 \%) \\
\text { NA - } 13(7.4 \%)\end{array}$ & $\begin{array}{l}\text { Correct - } 47(74.60 \%) \\
\text { Incorrect - } 15(23.80 \%) \\
\text { NA - } 1(1.58 \%)\end{array}$ \\
\hline
\end{tabular}

Table 2: Response regarding attitude of pharmacovigilance.

\begin{tabular}{|c|c|c|}
\hline Response to questions & JRs $n=$ number and (\%) & INTs $n=$ number and $(\%)$ \\
\hline $\begin{array}{l}\text { Which among the following factors discourage you } \\
\text { from reporting Adverse Drug Reactions? (Any one } \\
\text { only) }\end{array}$ & $\begin{array}{l}\text { Correct - } 14(19.71 \%) \\
\text { Incorrect - } 47(66.19 \%) \\
\text { NA - } 3(4.22 \%)\end{array}$ & $\begin{array}{l}\text { Correct - } 20(31.74 \%) \\
\text { Incorrect - } 39(61.90 \%) \\
\text { NA - } 4(6.34 \%)\end{array}$ \\
\hline $\begin{array}{l}\text { Do you think reporting is a professional obligation } \\
\text { for you? }\end{array}$ & $\begin{array}{l}\text { Correct - } 38(53.52 \%) \\
\text { Incorrect - } 31(43.66 \%) \\
\text { NA - } 3(4.22 \%)\end{array}$ & $\begin{array}{l}\text { Correct - } 37(58.73 \%) \\
\text { Incorrect }-26(41.26 \%)\end{array}$ \\
\hline $\begin{array}{l}\text { What is your opinion about establishing ADR } \\
\text { monitoring centre in every hospital? }\end{array}$ & $\begin{array}{l}\text { Correct - } 40(56.33 \%) \\
\text { Incorrect - } 28(39.43 \%) \\
\text { NA - } 3(4.22 \%)\end{array}$ & $\begin{array}{l}\text { Correct - } 37(58.73 \%) \\
\text { Incorrect }-26(41.26 \%)\end{array}$ \\
\hline $\begin{array}{l}\text { Do you think reporting of adverse drug reaction is } \\
\text { necessary? }\end{array}$ & $\begin{array}{l}\text { Correct - } 67(94.36 \%) \\
\text { Incorrect - } 4(5.36 \%)\end{array}$ & $\begin{array}{l}\text { Correct - } 62(98.41 \%) \\
\text { Incorrect - } 1(1.58 \%)\end{array}$ \\
\hline $\begin{array}{l}\text { Do you think Pharmacovigilance should be taught } \\
\text { in detail to healthcare professionals? }\end{array}$ & $\begin{array}{l}\text { Correct - } 66(92.95 \%) \\
\text { Incorrect } 4(5.63 \%) \\
\mathrm{NA}-1(1.40 \%)\end{array}$ & $\begin{array}{l}\text { Correct - } 59(93.65 \%) \\
\text { Incorrect - } 4(6.34 \%)\end{array}$ \\
\hline
\end{tabular}




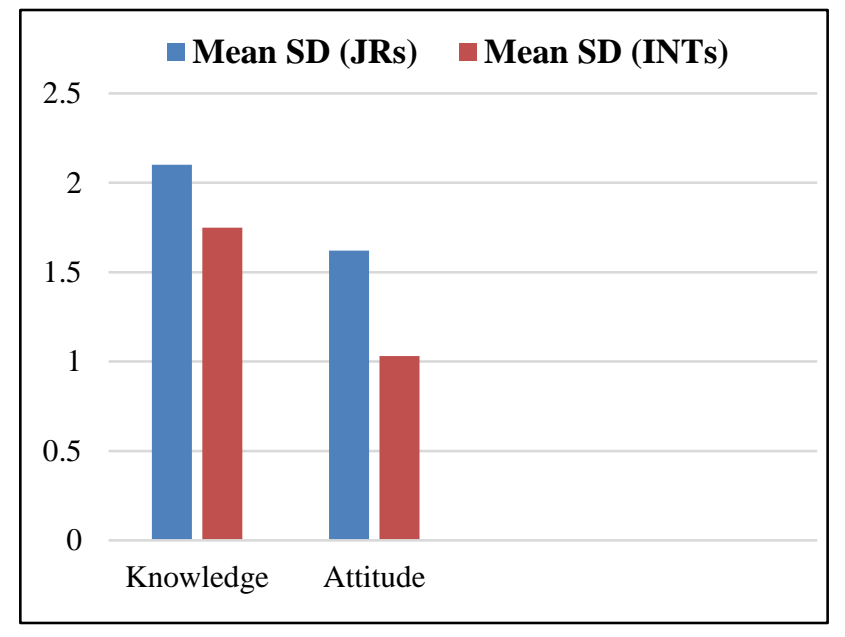

Figure 1: Knowledge score.

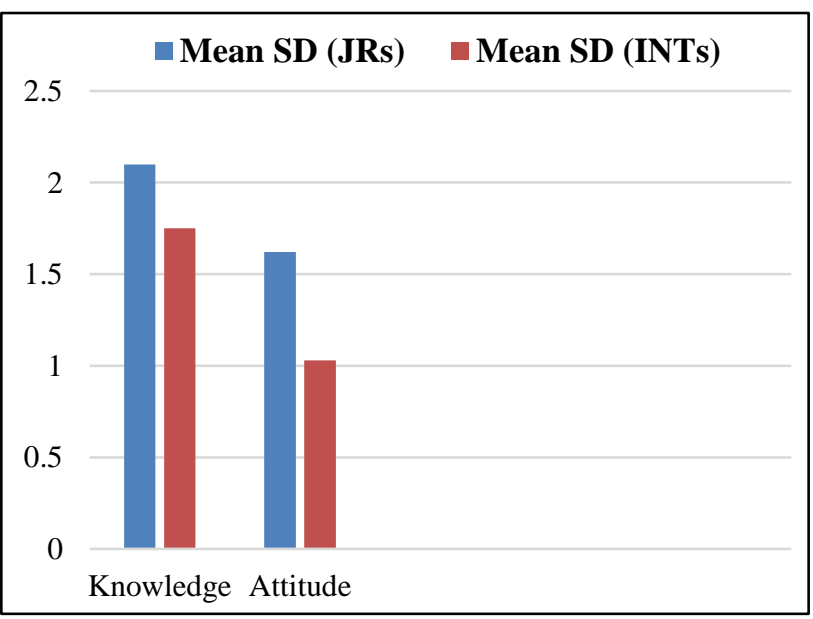

Figure 2: Attitude score.

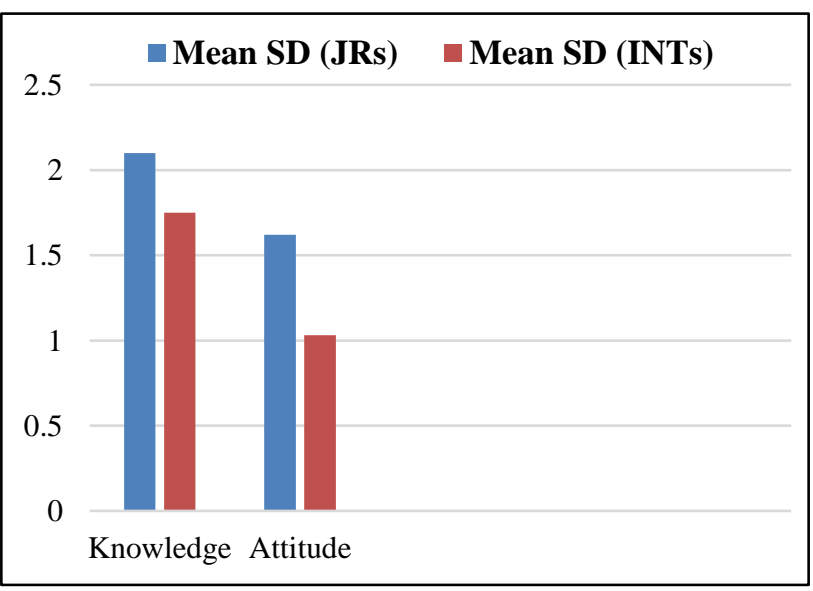

Figure 3: Mean knowledge and attitude score.

Table 3 shows response regarding practice of Pharmacovigilance. $37 \mathrm{Jr}$ and 31 INTs stated that they read an article on prevention of adverse drug reactions. $40 \mathrm{JR}$ and 39 INTs have come across adverse drug reaction induced by various drugs in the hospital. $52 \mathrm{JR}$ and 58 INTs stated that they have not been trained on how to report ADRs and basic orientation about pharmacovigilance.

Table 3: Response regarding practice of pharmacovigilance.

\begin{tabular}{|c|c|c|}
\hline $\begin{array}{l}\text { Response to } \\
\text { questions }\end{array}$ & $\begin{array}{l}\text { JRs } n= \\
\text { number and } \\
(\%)\end{array}$ & $\begin{array}{l}\text { INTs } n= \\
\text { number and } \\
(\%)\end{array}$ \\
\hline $\begin{array}{l}\text { Have you anytime } \\
\text { read any article on } \\
\text { prevention of } \\
\text { adverse drug } \\
\text { reactions? }\end{array}$ & $\begin{array}{l}\text { Correct - } 37 \\
(52.11 \%) \\
\text { Incorrect } 34 \\
(47.88 \%)\end{array}$ & $\begin{array}{l}\text { Correct - } 31 \\
(49.20 \%) \\
\text { Incorrect - } \\
32(50.79 \%)\end{array}$ \\
\hline $\begin{array}{l}\text { Have you ever } \\
\text { come across with } \\
\text { an ADR? }\end{array}$ & $\begin{array}{l}\text { Correct - } \\
40(56.33 \%) \\
\text { Incorrect - } \\
31(43.66 \%)\end{array}$ & $\begin{array}{l}\text { Correct - } 39 \\
(61.90 \%) \\
\text { Incorrect } 24 \\
(38.09 \%)\end{array}$ \\
\hline $\begin{array}{l}\text { Have you ever been } \\
\text { trained on how to } \\
\text { report Adverse } \\
\text { Drug Reaction } \\
\text { (ADR)? }\end{array}$ & $\begin{array}{l}\text { Correct - } \\
18(25.35 \%) \\
\text { Incorrect } \\
52(73.23 \%) \\
\text { NA - } 1(1.40 \%)\end{array}$ & $\begin{array}{l}\text { Correct - } 5 \\
(7.93 \%) \\
\text { Incorrect - } \\
58(92.6 \%)\end{array}$ \\
\hline
\end{tabular}

\section{DISCUSSION}

The present study is a questionnaire-based study to assess the knowledge, attitude and practice of pharmacovigilance towards ADR reporting among doctors in a tertiary care teaching hospital.

The essential component of pharmacovigilance is to report ADRs and spontaneous reporting system is important tool for reporting ADR and also new ADR of a new drug.

In the present study we observed that the knowledge of pharmacovigilance among doctors $63 \mathrm{JR}$ and 49 INTs had a knowledge score of less than $50 \%$. This shows that only few doctors are aware about the pharmacovigilance programme. A study conducted by Radhakrishnan $\mathrm{R}$ et al, that stated doctors were less aware or lack of knowledge of national and international pharmacovigilance program. ${ }^{11}$ In some other study or the literature noted, a lack of time and knowledge about ADRs is often considered to be a cause of underreporting. ${ }^{12-14}$ Inappropriate knowledge on drug interactions, food and drug interactions may mislead the healthcare professionals in recognizing and hence reporting an ADR, which ultimately may lead to poor practice of Pharmacovigilance.

The assessment of questionnaire based on attitude regarding pharmacovigilance shows that only $21 \mathrm{JR}$ and 17 of INTs had attitude score of $70 \%$ and above. In this study $38 \mathrm{JR}$ and 37 INTs stated ADR reporting is professional obligation for physicians. This attitude component is in much need of attention for improving underreporting of ADRs. Good knowledge and attitude remove the obstacles, misconceptions and barriers to the activities for practicing pharmacovigilance. $57 \%$ doctors 
stated that the establishment of ADR reporting center in every tertiary care hospital is necessary. 93\% of the participants in the present study supported the fact that the healthcare professionals should be sensitized about pharmacovigilance, which is very high when compared to Murararaih et al, study where only $58 \%$ of the participants were in favor of improving awareness about pharmacovigilance by educational programmes. ${ }^{15}$

Even as ADR reporting was considered to be important by a large majority of the participants but the actual practices of ADR reporting were very low. In this study, $29.4 \%$ of the respondents stated that they had come across an ADR previously. $82.2 \%$ of the participants stated that they have not been trained on how to report ADRs and basic orientation about pharmacovigilance which hinders the process of practicing pharmacovigilance.

The present study revealed that majority of the health-care professionals had knowledge and attitude about pharmacovigilance, but they lack in practice. Hence in order to improve practice of Pharmacovigilance there should be standardization for effective implementation of Pharmacovigilance: Regular training programmes, mandatory provision of ADR reporting forms in every inherent clinical departments by the institutions, regular electronic communication updates on the safety of drugs to all health care professionals, timely financial funding for such programmes in institutions, promotion of patient self-reporting, filling the communication gaps regarding Pharmacovigilance among healthcare professionals.

\section{CONCLUSION}

For the success of pharmacovigilance programmes only knowledge and attitude regarding Pharmacovigilance is not enough as is evident from present study. Success of Pharmacovigilance programmes depend also upon the effective practice of pharmacovigilance by healthcare professionals. There is a need for training and educational activities like CMEs for increasing the awareness about reporting of ADRs. Importance on adverse event reporting should be emphasized while teaching undergraduate and post graduate students.

Funding: No funding sources

Conflict of interest: None declared

Ethical approval: The study was approved by the Institutional Ethics Committee

\section{REFERENCES}

1. World Health Organization Collaborating Center for International Drug Monitoring. The importance of pharmacovigilance. Safety monitoring of medicinal products. Geneva: World Health Organization; 2002.

2. World Health Organization Collaborating Center for International Drug Monitoring. Geneva: World Health Organization; 1984. WHO publication DEM/NC/84.153 (E).
3. WHO. Safety of Medicines. A guide to detecting and reporting adverse drug reactions. Why health professionals need to take action. Geneva, World Health Organization; 2002. WHO/EDM/QSM/2002.2

4. Naranjo CA, Busto U, Sellers EM, Sandor P, Ruiz I, Roberts EA, et al. A method for estimating the probability of adverse drug reactions. Clin Pharmacol Ther. 1981;30(2):239-45.

5. John LJ, Mohamad A. Reporting of ADR: an exploratory study among nurses in a technical hospital. Ajman, United Arab Emirates. Daru J Pharm Sci. 2012;20(44):2-6.

6. Feely J, Moriarty S, O' Connor P: Stimulating reporting of adverse drug reaction by using a fee. $\mathrm{Br}$ Med J. 1990;300:22-3.

7. Smith CC, Bennett PM, Pearce HM, Harrison PI, Reynolds DJM, Aronson JK, et al. Adverse drug reactions in a hospital general medical unit meriting notification to the Committee on Safety of Medicines. Br J Clin Pharmacol. 1996;42:423-9.

8. Lee KK, Chan TY, Raymond K, Critchley JA. Pharmacists' attitudes toward adverse drug reaction reporting in Hong Kong. Ann Pharmacother. 1994;28(12):1400-3.

9. Aziz Z, Siang TC, Badarudin NS. Reporting of adverse drug reactions: predictors of under-reporting in Malaysia. Pharmacoepidemiol Drug Saf. 2007;16(2):223-8.

10. Herdeiro MT, Figueiras A, Polónia J, Gestal-Otero JJ. Physicians' attitudes and adverse drug reaction reporting: a case-control study in Portugal. Drug Saf. 2005;28:825-33.

11. Radhakrishnan R, Vidyasagar S, Varma DM. An educational intervention to assess knowledge attitude practice of pharmacovigilance among Health care professionals in an Indian tertiary care teaching hospital. Int J Pharm Tech Res. 2011;3:678-92.

12. Ramesh M, Parthasarathi G. Adverse drug reactions reporting: Attitudes and perceptions of medical practitioners. Asian J Pharm Clin Res. 2009;2:10-4.

13. Lopez-Gonzalez E, Herdeiro MT, Figueiras A. Determinants of under-reporting of adverse drug reactions: A systematic review. Drug Saf. 2009;32:1931. [PubMed: 19132802]

14. Eland IA, Belton KJ, van Grootheest AC, Meiners AP, Rawlins MD, Stricker BH. Attitudinal survey of voluntary reporting of adverse drug reactions. $\mathrm{Br} \mathrm{J}$ Clin Pharmacol. 1999;48:623-7. [PMCID: PMC2014371] [PubMed: 10583035]

15. Muraraiah S, Rajarathna K, Sreedhar D, Basavalingu D, Jayanthi CR. A questionnaire study to assess the knowledge, attitude and practice of Pharmacovigilance in a paediatric tertiary care centre. J Chem Pharm Res. 2011;3(6):416-22.

Cite this article as: Korde RA, Radhika MS. A KAP study of pharmacovigilance among junior residents and interns of a tertiary care hospital. Int J Basic Clin Pharmacol 2018;7:2178-83. 
Annexure I: Questionnaire for KAP survey on pharmacovigilance.

\begin{tabular}{|c|c|}
\hline Questions & Options \\
\hline $\begin{array}{l}\text { Define Pharmacovigilance? (Most appropriate } \\
\text { any one only) }\end{array}$ & $\begin{array}{l}\text { a) The science of monitoring ADR's happening in a Hospital } \\
\text { b) The process of improving the safety of Drugs } \\
\text { c) The detection, assessment, understanding \& prevention of adverse } \\
\text { effects } \\
\text { d) The science detecting the type \& incidence of ADR after drug is } \\
\text { marketed. }\end{array}$ \\
\hline $\begin{array}{l}\text { The important purpose of Pharmacovigilance is } \\
\text { (Most appropriate one) }\end{array}$ & $\begin{array}{l}\text { a) To identify safety of drugs b) To calculate incidence of ADR's } \\
\text { c) To identify predisposing factors to ADR's d) To identify } \\
\text { unrecognized ADRs }\end{array}$ \\
\hline $\begin{array}{l}\text { A serious adverse Event in India should be } \\
\text { reported to the Regulatory body within }\end{array}$ & $\begin{array}{l}\text { a) One day b) Seven calendar days c) Fourteen calendar days d) } \\
\text { Fifteen } \\
\text { Calendar days }\end{array}$ \\
\hline $\begin{array}{l}\text { The international centre for adverse drug } \\
\text { reaction monitoring is located in }\end{array}$ & a) Unites States of America b) Australia c) France d) Sweden \\
\hline $\begin{array}{l}\text { One of the following is the agency in Unites } \\
\text { States of America involved in drug safety } \\
\text { issues. }\end{array}$ & $\begin{array}{l}\text { a) American Society of Health System Pharmacists (ASHP) } \\
\text { b) United States food and drug administration (US FDA) } \\
\text { c) American Medical Association (AMA) } \\
\text { d) American Pharmaceutical Association (APA }\end{array}$ \\
\hline $\begin{array}{l}\text { In India which Regulatory body is responsible } \\
\text { for monitoring of ADR's? }\end{array}$ & $\begin{array}{l}\text { a) Central Drugs Standard Control Organization b) Indian Institute of } \\
\text { sciences c) Pharmacy Council of India d) Medical Council of India }\end{array}$ \\
\hline $\begin{array}{l}\text { Which of the following scales is most } \\
\text { commonly used to establish the causality of an } \\
\text { ADR? }\end{array}$ & $\begin{array}{l}\text { a) Hartwig scale b) Naranjo algorithm c) Schumock and Thornton } \\
\text { scale d) Karch and Lasagna scale }\end{array}$ \\
\hline $\begin{array}{l}\text { Match the ADR reporting systems to the } \\
\text { respective countries. (Write the number in the } \\
\text { appropriate boxes) }\end{array}$ & $\begin{array}{l}\text { 1) Yellow card India } \\
\text { 2) Green card Australia } \\
\text { 3) ADR reporting Form United Kingdom } \\
\text { 4) Blue card Scotland }\end{array}$ \\
\hline $\begin{array}{l}\text { One among these is a Regional } \\
\text { Pharmacovigilance centre? }\end{array}$ & $\begin{array}{l}\text { a) SDM medical college \& hospital b) JIPMER, Pondicherry c) JSS } \\
\text { Medical College \& Hospital, Mysore d) CMC, Vellore }\end{array}$ \\
\hline $\begin{array}{l}\text { Which one of the following is the 'WHO online } \\
\text { database' for reporting ADRs? }\end{array}$ & a) ADR advisory committee b) Medsafe c) Vigibase d) Med watch \\
\hline $\begin{array}{l}\text { Rare ADRs can be identified in the following } \\
\text { phase of a clinical trial }\end{array}$ & $\begin{array}{l}\text { a) During phase- } 1 \text { clinical trials b) During phase- } 2 \text { clinical trials c) } \\
\text { During phase- } 3 \text { clinical trials d) During phase- } 4 \text { clinical trials }\end{array}$ \\
\hline $\begin{array}{l}\text { The healthcare professionals responsible for } \\
\text { reporting ADR in a hospital is/are }\end{array}$ & a) Doctor b) Pharmacist c) Nurses d) All of the above \\
\hline $\begin{array}{l}\text { Which among the following factors discourage } \\
\text { you from reporting Adverse Drug Reactions? } \\
\text { (Any one only) }\end{array}$ & $\begin{array}{l}\text { a) Non-remuneration for reporting b) Lack of time to report ADR } \\
\text { c) A single unreported case may not affect ADR database } \\
\text { d) Difficult to decide whether ADR has occurred or not }\end{array}$ \\
\hline $\begin{array}{l}\text { Do you think reporting is a professional } \\
\text { obligation for you? }\end{array}$ & a) Yes b) No c) Don't know d) Perhaps \\
\hline $\begin{array}{l}\text { What is your opinion about establishing ADR } \\
\text { monitoring centre in every hospital? }\end{array}$ & $\begin{array}{l}\text { a) Should be in every hospital b) Not necessary in every hospital c) } \\
\text { One in a city is sufficient d) Depends on number of bed size in the } \\
\text { hospitals. }\end{array}$ \\
\hline $\begin{array}{l}\text { Do you think reporting of adverse drug reaction } \\
\text { is necessary? }\end{array}$ & a) Yes b) No \\
\hline $\begin{array}{l}\text { Do you think Pharmacovigilance should be } \\
\text { taught in detail to healthcare professionals? }\end{array}$ & a) Yes b) No \\
\hline $\begin{array}{l}\text { Have you anytime read any article on } \\
\text { prevention of adverse drug reactions? }\end{array}$ & a) Yes b) No \\
\hline Have you ever come across with an ADR? & a) Yes b) No \\
\hline $\begin{array}{l}\text { Have you ever been trained on how to report } \\
\text { Adverse Drug Reaction (ADR)? }\end{array}$ & a) Yes b) No \\
\hline
\end{tabular}

